\title{
PENGARUH PENDEKATAN ELPSA (EXPERIENCES, LANGUAGE, PICTURES, SYMBOLS, AND APPLICATION) TERHADAP PEMBELAJARAN MATEMATIKA SISWA KELAS VIII
}

\author{
Nursakiah $^{1}$, Rezki Ramdani ${ }^{2}$, Andi Mulawakkan Firdaus ${ }^{3}$, Muhammad Muzaini ${ }^{4}$ \\ Universitas Muhammadiyah Makassar ${ }^{1,2,3}$, Universitas Cokroaminoto Palopo ${ }^{4}$ \\ Nursakiah@unismuh.ac.id ${ }^{1}$, andi.mulawakkan@unismuh.ac.id ${ }^{3}$
}

\begin{abstract}
Abstrak
Penelitian ini bertujuan untuk mengetahui pengaruh pendekatan ELPSA (Experiences, Language, Pictures, Symbols, and Application) terhadap pembelajaran matematika siswa kelas VIII SMP Negeri 6 Makassar. Jenis penelitian yang digunakan adalah penelitian eksperimen. Desain penelitian ini adalah One-Grup Pretest-Posttest Design. Populasi dalam penelitian ini adalah seluruh siswa kelas VIII SMP Negeri 6 Makassar tahun ajaran 2019/2020 dan selanjutnya dipilih satu kelas sebagai sampel penelitian yang diberikan perlakuan dengan menggunakan pendekatan ELPSA dengan teknik Cluster Random Sampling. Instrumen dalam penelitian ini adalah tes kemampuan matematika. Teknik analisis data yang digunakan adalah analisis deskriptif dan analisis inferensial. Hasil analisis deskriptif menunjukkan bahwa: (1) terjadi peningkatan kemampuan matematika setelah diterapkan pendekatan pembelajaran ELPSA; (2) skor kemampuan matematika setelah diterapkan pendekatan pembelajaran ELPSA memenuhi kriteria ketuntasan yaitu lebih dari 80; dan (3) ketuntasan kemampuan matematika siswa setelah diterapkan pendekatan pembelajaran ELPSA tuntas secara klasikal yaitu mencapai 97\%. Hasil analisis inferensial menunjukkan bahwa penerapan pendekatan ELPSA (Experiences, Language, Pictures, Symbols, and Application) berpengaruh terhadap kemampuan matematika siswa kelas VIII SMP Negeri 6 Makassar.
\end{abstract}

Kata Kunci: Pendekatan ELPSA, Pembelajaran Matematika

\section{A. Pendahuluan}

Perkembangan ilmu pengetahuan dan teknologi (IPTEK) yang semakin pesat telah membawa implikasi perubahan dalam dunia pendidikan. Dunia pendidikan sangat terkait dengan siswa sebagai peserta didik yang merupakan subjek utama dalam pendidikan. Peserta didik harus dibekali dengan pengetahuan, keterampilan dan sikap yang memungkinkannya untuk mandiri, sehingga dapat memberikan kontribusi yang bermanfaat bagi pembangunan bangsa dan negara. Menurut UU No. 20 tahun 2003 bahwa: "Pendidikan adalah usaha sadar dan terencana untuk mewujudkan suasana belajar dan proses pembelajaran agar 
peserta didik secara aktif mengembangkan potensi dirinya untuk memiliki kegiatan spiritual keagamaan, pengendalian diri, kepribadian, kecerdasan, akhlak mulia, serta keterampilan dirinya, masyarakat, bangsa, dan negara”. Pendidikan memiliki peranan yang sangat penting dalam pembangunan manusia Indonesia seutuhnya. Oleh karena itu pendidikan sangat perlu untuk dikembangkan dari berbagai ilmu pengetahuan, sebab pendidikan yang berkualitas dapat meningkatkan kualitas suatu bangsa. Pendidikan merupakan bagian penting dari proses pembangunan nasional yang ikut meningkatkan pertumbuhan ekonomi suatu negara. Pendidikan juga merupakan investasi dalam pengembangan sumber daya manusia dalam peningkatan kecakapan dan kemampuan sebagai faktor pendukung upaya manusia dalam mengarungi kehidupan. Salah satu pengetahuan dalam pendidikan yang mampu mengembangkan daya pikir manusia adalah pengetahuan matematika.

Matematika merupakan pengetahuan universal yang mendasari perkembangan teknologi modern, mempunyai peran penting dalam berbagai disiplin ilmu dan mengembangkan daya pikir manusia (Firdaus, 2019). Dengan mempelajari matematika, siswa diharapkan dapat berpikir secara logis, analitis, kritis, dan kreatif serta diharapkan mampu memecahkan segala masalah yang dihadapi, baik masalah yang berkaitan dengan pelajaran matematika, maupun yang berkaitan dengan kehidupan sehari-hari. Kurikulum 2013 menuntut proses pembelajaran matematika diarahkan pada pembelajaran menemukan konsepkonsep matematika, belajar dari permasalahan real sesuai dengan prinsip pembelajaran konstruktivisme dengan menggunakan pendekatan ilmiah (scientific approach) dimana peserta didik mendapatkan pengalaman belajar melalui proses 6M (mengamati, menanya, mengeksplorasi atau mencoba, menalar atau menyimpulkan, mengkomunikasikan atau membuat jejaring, dan mencipta atau membuat karya kreatif) (Kemendikbud, 2013).

Sejalan dengan tujuan umum pembelajaran matematika pada jenjang pendidikan dasar dan menengah menurut Soedjadi (Mulbar, Bernard, \& Pesona, 2018) yaitu: 1) Memahami konsep matematika, menjelaskan keterkaitan antar konsep dan mengaplikasikan konsep atau algoritma secara luwes, akurat, efesien, dan tepat dalam pemecahan masalah; 2) Menggunakan penalaran pada pola dan 
sifat, melakukan manipulasi matematika dalam membuat generalisasi, menyusun bukti, atau menjelaskan gagasan dan pernyataan matematika; 3) Memecahkan masalah yang meliputi kemampuan memahami masalah, merancang model matematika, menyelesaikan model dan menafsirkan solusi yang diperoleh; 4) Mengkomunikasikan gagasan dengan simbol, tabel, diagram, atau media lain untuk memperjelas keadaan atau masalah; 5) Memiliki sikap menghargai kegunaan matematika dalam kehidupan, yaitu memiliki rasa ingin tahu, perhatian, dan minat dalam mempelajari matematika, serta sikap ulet dan percaya diri dalam pemecahan masalah.

Sesuai dengan tuntutan kurikulum, tujuan pembelajaran matematika, dan fakta-fakta yang terjadi di sekolah, maka setelah proses pembelajaran siswa diharapkan dapat memahami konsep matematika sehingga dapat menggunakan kemampuannya dalam menghadapi masalah-masalah matematika (Listiawati, 2018). Menurut Mulbar, Bernard, \& Pesona (2018) dalam pendidikan matematika, memahami konsep-konsep matematika merupakan dasar penting untuk berpikir dalam memecahkan masalah matematika dan masalah kehidupan nyata.

Untuk meningkatkan kemampuan matematika siswa harus didukung dengan pendekatan pembelajaran yang tepat. Salah satu pendekatan pembelajaran yang dapat meningkatkan kemampuan matematika siswa yaitu dengan pendekatan pembelajaran ELPSA yang memuat lima komponen, yaitu Experiences, Language, Pictures, Symbols, dan Application. Menurut Johar, et.al. (2016) bahwa ELPSA framework menjadikan seorang individu mengembangkan konsep matematika secara bermakna. Sedangkan menurut Wijaya (2014), menunjukkan bahwa komponen application dalam ELPSA merupakan kegiatan pembelajaran yang berusaha memahami signifikansi proses belajar dengan mengaplikasikan pengetahuan baru dalam memecahkan masalah dalam konteks yang bermakna. Pembelajaran pendekatan ELPSA (Experiences, Language, Pictures, Symbols, dan Application) bermaksud untuk memberikan ruang gerak berpikir yang bebas kepada siswa untuk mencari konsep dan penyelesaian masalah yang terkait dengan materi yang diajarkan guru di sekolah.

Pada dasarnya ilmu matematika bertujuan agar siswa memahami konsep matematika dan keterkaitannya dengan kehidupan sehari-hari, memiliki 
keterampilan untuk mengembangkan pengetahuan tentang proses alam sekitar, mampu menerapkan berbagai konsep matematika untuk menjelaskan gejala alam dan mampu menggunakan teknologi sederhana untuk memecahkan masalah yang ditemukan dalam kehidupan sehari-hari. Penelitian ini bertujuan untuk mengetahui pengaruh pendekatan ELPSA (Experiences, Language, Pictures, Symbols, and Application) terhadap pembelajaran matematika siswa kelas VIII SMP Negeri 6 Makassar.

\section{B. Metode Penelitian}

Penelitian ini merupakan penelitian eksperimen yang dilaksanakan di SMP Negeri 6 Makassar. Penelitian yang dilakukan bertujuan untuk mengetahui pengaruh pendekatan ELPSA (Experiences, Language, Pictures, Symbols, dan Application) terhadap kemampuan matematika siswa kelas VIII SMP Negeri 6 Makassar. Desain penelitian yang digunakan adalah desain One-Grup PretestPosttest Design (Ma'rup \& Firdaus, 2020). Populasi dalam penelitian ini adalah seluruh siswa kelas VIII SMP Negeri 6 Makassar tahun ajaran 2019/2020 dan selanjutnya dipilih satu kelas sebagai sampel penelitian yaitu kelas VIII yang diberikan perlakuan dengan menggunakan pendekatan pembelajaran ELPSA dengan teknik Cluster Random Sampling.

Instrumen yang digunakan dalam penelitian ini adalah lembar observasi keterlaksanaan pembelajaran yang bertujuan untuk mengetahui seberapa baik keterlaksanaan pendekatan pembelajaran ELPSA. Tes kemampuan matematika dengan mengacu pada kompetensi dasar dan indikator yang bertujuan untuk mengukur kemampuan matematika siswa setelah penerapan pendekatan pembelajaran ELPSA. Teknik pengumpulan data dalam penelitian ini adalah lembar observasi keterlaksanaan pendekatan pembelajaran ELPSA dan tes kemampuan matematika yang diberikan setelah penerapan pendekatan pembelajaran ELPSA pada siswa kelas VIII SMP Negeri 6 Makassar.

Teknik analisis dalam penelitian ini dengan menggunakan statistik deskriptif dan statistik inferensial. Analisis statistik deskriptif bertujuan untuk mengetahui pemahaman materi melalui penggambaran karakeristik distribusi nilai pencapaian kemampuan matematika siswa melalui pendekatan pembelajaran ELPSA (Firdaus, et al, 2020). Sedangkan statistik Inferensial bertujuan untuk 
melakukan generalisasi yang meliputi estimasi (perkiraan) dan pengujian hipotesis berdasarkan data yang diperoleh dari skor hasil kemampuan matematika siswa (Muzaini, 2016).

\section{Hasil Dan Pembahasan}

Hasil analisis menunjukkan bahwa keterlaksanaan pembelajaran dengan penerapan pendekatan pembelajaran ELPSA pada pertemuan pertama adalah 3,37 berada pada kategori terlaksana dengan sangat baik, pertemuan kedua diperoleh rata-rata 3,58 berada pada kategori terlaksana dengan sangat baik, pertemuan ketiga diperoleh rata-rata 3,68 berada pada kategori terlaksana dengan sangat baik, pertemuan keempat diperoleh rata-rata 3,63 berada pada kategori terlaksana dengan sangat baik, pertemuan kelima diperoleh rata-rata 3,63 berada pada kategori terlaksana dengan sangat baik, dan pertemuan kenam diperoleh rata-rata 3,68 berada pada kategori terlaksana dengan sangat baik. Berdasarkan uraian tersebut, dapat disimpulkan bahwa dalam proses pembelajaran dengan menerapkan pendekatan ELPSA kemampuan guru dalam mengelola pembelajaran selama 6 kali pertemuan terlaksana dengan sangat baik.

Selanjutnya hasil belajar kemampuan matematika siswa setelah menerapkan pendekatan ELPSA pada siswa kelas VIII SMP Negeri 6 Makassar.

Tabel 1. Hasil Kemampuan Matematika Siswa Kelas VIII SMP Negeri 6

\begin{tabular}{ccc}
\multicolumn{3}{c}{ Makassar } \\
\hline Statistik & PRETEST_PK & POSTTEST_PK \\
\hline Ukuran Sampel & 33 & 33 \\
Mean & 40.9697 & 91.3333 \\
Median & 40.0000 & 92.0000 \\
Modus & $25.00^{\mathrm{a}}$ & 95.00 \\
Std. Deviasi & 11.88614 & 5.59948 \\
Variansi & 141.280 & 31.354 \\
Skewness & 0.223 & -0.318 \\
Range & 35.00 & 20.00 \\
Nilai Terendah & 25.00 & 80.00 \\
Nilai Tertinggi & 60.00 & 100.00 \\
\hline
\end{tabular}

Dari tabel di atas, terlihat bahwa mean posttest kemampuan matematika siswa adalah 91,33. Hal ini menunjukkan bahwa secara umum nilai posttest tersebut berada pada kategori sangat tinggi, dengan demikian ada peningkatan 
perolehan nilai mean siswa dari pretest ke posttest (dari kategori sangat rendah ke sangat tinggi). Nilai median posttest siswa sebesar 92,00 menunjukkan bahwa ada sekitar 50\% siswa yang memperoleh nilai paling tinggi 92,00 atau paling rendah 92,00. Adapun nilai modus sebesar 95,00 menunjukkan bahwa posttest kemampuan matematika siswa dengan frekuensi terbesar adalah 95,00. Berdasarkan koefisien kemiringan sebesar -0,31 dan memperhatikan nilai mean, median dan modus, dapat dikatakan bahwa secara umum hasil posttest kemampuan matematika siswa berada di atas rata-rata dengan kategori sangat tinggi.

Tabel 2. Klasifikasi Gain Ternormalisasi kemampuan matematika Siswa

\begin{tabular}{cccc}
\hline Koefisien normalisasi gain & Klasifikasi & Jumlah siswa & Persentase (\%) \\
\hline $\mathrm{g} \geq 0,7$ & Tinggi & 32 & 97 \\
$0,3<\mathrm{g}<0,7$ & Sedang & 1 & 3 \\
$\mathrm{~g} \leq 0,3$ & Rendah & 0 & 0 \\
\hline Jumlah & & 33 & 100 \\
\hline
\end{tabular}

Dari tabel tersebut dapat dilihat bahwa 32 siswa berada pada kategori tinggi dengan persentase $97 \%$ dan 1 siswa berada pada kategori sedang dengan persentase 3\%. Tidak satupun siswa yang memperoleh skor dalam kategori rendah. Hal ini memberikan indikasi bahwa peningkatan kemampuan matematika siswa setelah diterapkan pendekatan pembelajaran ELPSA dikelas VIII SMP Negeri 6 Makassar berada pada ketegori tinggi dengan persentase 97\%. Berdasarkan uraian di atas dapat disimpulkan bahwa secara deskriptif peningkatan kemampuan siswa setelah diterapkan pendekatan pembelajaran ELPSA pada kelas VIII SMP Negeri 6 Makassar berada pada ketegori tinggi dengan persentase 97\%.

Tabel 3. Persentase Skor Kemampuan Matematika Siswa

\begin{tabular}{cccc}
\hline No. & Kemampuan & Persentase $(\%)$ & Kategori \\
\hline 1 & Pemahaman Matematika & 93.43 & Sangat tinggi \\
2 & Komunikasi Matematika & 92,93 & Sangat tinggi \\
3 & Representasi Matematis & 91,08 & Sangat tinggi \\
4 & Koneksi Matematis & 89,20 & Tinggi \\
\hline & Rerata & 91,66 & Sangat tinggi \\
\hline
\end{tabular}

Dari tabel tersebut telah dilakukan analisis data dan diperoleh skor kemampuan pemahaman matematika siswa mencapai 93,43\% dengan kategori sangat tinggi, skor kemampuan komunikasi matematika siswa mencapai 92,93\% 
dengan kategori sangat tinggi, skor kemampuan representasi matematis mencapai 91,08\% dengan kategori sangat tinggi, dan skor kemampuan koneksi matematis siswa mencapai $89,20 \%$ dengan kategori tinggi. Sehingga dapat disimpulkan bahwa secara deskriptif kemampuan matematika siswa kelas VIII SMP Negeri 6 Makassar dikategorikan sangat tinggi dengan persentase keseluruhan tiap indikator pemahaman konsep mencapai 91,66\%.

Berdasarkan hasil penelitian telah dideskripsikan bahwa hasil kemampuan matematika siswa setelah menerapkan pendekatan pembelajaran ELPSA adalah meningkat. Terjadinya peningkatan kemampuan matematika siswa adalah pengaruh dari penerapan pendekatan pembelajaran ELPSA. Sehingga, pada pembahasan ini dideskripsikan pengaruh komponen pendekatan ELPSA terhadap setiap kemampuan matematika siswa. Pendekatan ELPSA yang meliputi experiences, language, pictures, symbols, and aplication berpengaruh terhadap setiap kemampuan matematika yaitu:

a) Experiences $(\mathrm{E})=$ Pengalaman

Experiences (Pengalaman) merupakan kegiatan pembelajaran yang mengeksplisitkan atau memunculkan pengalaman terdahulu yang dimiliki siswa dan menghubungkannya dengan pengetahuan dan pengalaman atau informasi baru yang akan diperoleh atau dipelajari. Pada tahap ini siswa mampu memahami, mengkomunikasikan, merepresentasikan, dan menghubungkan matematika berdasarkan pengalaman dan pengetahuan yang telah dipelajari atau dialami secara kontekstual

Menurut Arifin (2015) pengalaman meliputi bagaimana para siswa menggunakan matematika selama ini, konsep apa saja yang mereka ketahui, bagaimana mereka dapat memperoleh informasi, dan bagaimana matematika itu telah dialami oleh siswa baik di dalam maupun di luar kelas. Pengetahuan terbangun disaat siswa berusaha untuk mengorganisasikan pengalamannya sesuai dengan struktur kognitif yang dimilikinya.

b) Language $(\mathrm{L})=$ Bahasa

Language (Pengembangan bahasa) merupakan kegiatan pembelajaran yang secara aktif mengembangkan bahasa matematika tertentu agar dimaknai oleh pembelajar. Penting bagi guru untuk memodelkan bahasa yang benar dan siswa 
perlu didorong menggunakan bahasa yang jelas dalam mendeskripsikan pemahamannya kepada guru dan teman-temannya. Pada tahap ini siswa mampu memahami, mengkomunikasikan, merepresentasikan, dan menghubungkan matematika berdasarkan kemampuan dalam mengembangkan bahasa, yaitu: saat guru menyampaikan atau menjelaskan materi dan menyebutkan perumpamaan atau contoh dengan bahasa yang jelas dan mudah dipahami oleh siswa, oleh karena itu siswa mampu menggunakan bahasa yang jelas dalam mendeskripsikan pemahamannya kepada guru dan teman-temannya.

Menurut Sutawidjaya (Johar et al., 2016) Bahasa digunakan untuk mendorong terjadinya pemahaman. Dalam matematika, bahasa matematika bisa bersifat umum maupun khusus dan diperlukan untuk menyajikan ide-ide matematika. Bisa terjadi siswa tidak memahami suatu konsep matematika bukan karena konsep itu terlalu sulit baginya tetapi karena guru yang menyajikan menggunakan kata atau kalimat yang tidak bisa dimengerti oleh siswa.

c) Pictures $(\mathrm{P})=$ Gambar

Pictures (representasi gambar) merupakan kegiatan pembelajaran yang memberikan pengalaman mengenai konsep matematika dalam bentuk gambar. Pada tahap ini siswa mampu memahami, mengkomunikasikan, merepresentasikan, dan menghubungkan matematika berdasarkan gambar atau objek yang dilihatnya.

Menurut Alcock \& Simpson (2004), bahwa visualisasi penting dalam berpikir matematis yang dapat diwujudkan dalam bentuk bayangan (image) gambar pada kertas ataupun tampilan dari teknologi. Representasi gambar (komponen "P" dari ELPSA) dapat digunakan untuk merangsang siswa berpikir matematis yaitu gambar atau visualisasi seperti apa yang lebih efektif dalam membantu siswa memahami matematika yang bisa menjadi batu loncatan bagi siswa untuk sampai pada komponen "S" dari ELPSA.

d) Symbols $(\mathrm{S})=$ Simbol

Symbols (representasi simbol) merupakan kegiatan pembelajaran yang dapat mengubah atau melakukan transisi dari representasi gambar ke representasi simbol. Konsep matematika memuat banyak simbol, baik berupa rumus ataupun pernyataan yang abstrak. Pada tahap ini siswa mampu memahami, 
mengkomunikasikan, merepresentasikan, dan menghubungkan matematika berdasarkan symbol yang merupakan transisi dari refresentasi gambar.

Menurut Ismail \& Laili (2016) menegaskan bahwa Simbol dalam ELPSA merupakan pengalaman yang lebih umum dan merupakan hasil generalisasi. Rangkaian simbol-simbol dalam matematika dapat berbentuk suatu model matematika. Simbol dalam matematika dapat mengantarkan pengetahuan siswa untuk menemukan solusi dan menerapkan rumus dalam menyelesaikan soal matematika.

e) Aplication (I) = Aplikasi pengetahuan

Application (penerapan pengetahuan) merupakan kegiatan pembelajaran yang berusaha memahami signifikansi proses belajar dengan mengaplikasikan pengetahuan baru dalam memecahkan masalah dalam konteks yang bermakna. Pada tahap ini siswa mampu memahami, mengkomunikasikan, merepresentasikan, dan menghubungkan matematika berdasarkan pengetahuan yang diperoleh dari semua komponen atau langkah-langkah pembelajaran pendekatan ELPSA yaitu, experiences, language, pictures, symbols, and aplication.

Menurut Lowrie \& Patahuddin (2015) bahwa tahapan aplikasi menggambarkan bagaimana pengetahuan dan pemamahan konsep yang telah diperoleh dapat diterapkan dalam bermacam-macam situasi. Dengan demikian, pada komponen aplikasi siswa menggunakan kemampuan pemahaman konsep dalam memecahkan suatu masalah.

\section{Kesimpulan Dan Saran}

Adapun kesimpulan dari penelitian ini adalah pendekatan ELPSA (experiences, language, pictures, symbol and aplication) berpengaruh terhadap kemampuan matematika siswa kelas VIII SMP Negeri 6 Makassar, yaitu kemampuan matematika siswa setelah penerapan pendekatan ELPSA kelas VIII SMP Negeri 6 Makassar mencapai rata-rata skor posttest sebesar 91,33; rata-rata gain ternormalisasi sebesar 0,86; ketuntasan secara klasikal sebesar 97\%; persentase kemampuan matematika sebesar 91,66\%; standar deviasi sebesar 5,60; dan nilai tertinggi mencapai 100. Pendekatan ELPSA yang meliputi experiences, 
language, pictures, symbols, and aplication berpengaruh terhadap setiap indikator kemampuan matematika, yaitu indikator I $(93,43 \%)$ siswa mampu memahami matematika pada tahap experiences, language, dan picture. Indikator II $(92,93 \%)$ Siswa mampu mengkomunikasikan matematika pada tahap language dan pictures, indikator III $(91,08 \%)$ siswa mampu merepresentasikan matematika pada tahap Language, pictures dan symbols, indikator IV $(89,20 \%)$ siswa mampu menghubungkan matematika pada tahap symbols dan aplication.

Berdasarkan hasil penelitian yang telah dicapai dalam penelitian ini, maka dikemukakan beberapa saran bahwa dalam proses pembelajaran diharapkan menggunakan langkah-langkah pembelajaran minimal seperti langkah-langkah pembelajaran pendekatan ELPSA yaitu Experiences (Pengalaman), Language (pengembangan bahasa), Pictures (representasi gambar), Symbol (representasi symbol), dan Aplication (aplikasi pengetahuan) untuk meningkatkan kemampuan matematika siswa.

\section{Daftar Pustaka}

Alcock, L., \& Simpson, A. (2004). Convergence of sequences and series: Interactions between visual reasoning and the learner's beliefs about their own role. Educational Studies in Mathematics, 57(1), 1-32.

Arifin. (2015). Lesson Plan Berbasis Kerangka Kerja ELPSA untuk Membangun Pemahaman Konsep Penjumlahan dan Pengurangan Bilangan Bulat pada Siswa. Jurnal Kependidikan, 14 (1), 11-21.

Listiawati, E. (2018). Analisis Pemahaman Siswa SD Dalam Menyelesaikan Masalah Kalimat Matematika. APOTEMA: Jurnal Program Studi Pendidikan Matematika, 4(2), 10-18.

Firdaus, A. M. (2019). Application of Cooperative Learning Model Type Think Pair Share (Tps) on Mathematical Communication Ability. Jurnal Daya Matematis, 7(1), 59. https://doi.org/10.26858/jds.v7i1.8846

Firdaus, A. M., Juniati, D., \& Wijayanti, P. Number pattern generalization process by provincial mathematics olympiad winner students. Journal for the Education of Gifted Young Scientists, 8(3), 991-1003.

Ismail \& Laili, I. (2016). Perancangan Pembelajaran dengan Kerangka Kerja ELPSA (Experience, Language, Pictorial, Symbol, And Application) pada Materi Prisma Kelas VIII SMP. Jurnal Ilmiah Pendidikan Matematika, 3(5), 2301-908. 
Johar, R., Nurhalimah, \& Yuzrizal. (2016). Desain Pembelajaran Elpsa Pada Materi Pencerminan. Edumatica, 6.

Kemendikbud, R. I. (2013). No Title. Bahan Pelatihan Kurikulum 2013.

Lowrie, T., \& Patahuddin, S. M. (2015). ELPSA as a Lesson Design Framework. Journal on Mathematics Education, 6(2), 77-92.

Ma'rup, M., \& Firdaus, A. M. (2020). Efektivitas Pembelajaran Matematika Melalui Penerapan Model Kooperatif Tipe Talking Stick Pada Siswa Kelas VII SMP. Jurnal Edukasi Matematika Dan Sains, 8(1), 79. https://doi.org/10.25273/jems.v8i1.6049

Masfingatin, T., \& Murtafiah, W. (2020). Exploring The Creative Mathematical Reasoning of Mathematics Education Student Through Discovery Learning. AKSIOMA: Jurnal Program Studi Pendidikan Matematika, 9(2), 296-305.

Mulbar, U., Bernard, B., \& Pesona, R. R. (2018). Penerapan Model Pembelajaran Berbasis Masalah dengan Strategi Pembelajaran Diferensiasi pada Peserta Didik Kelas VIII. Issues in Mathematics Education (IMED), 1(1), 1-6.

Muzaini, M. (2016). Pengaruh pendekatan problem posing terhadap prestasi belajar matematika siswa berdasarkan gaya kognitif. Beta: Jurnal Tadris Matematika, 9(2), 161-179. 